\title{
PERFORMANCE OF INOCULATED COMMON BEAN IN RESPONSE TO DIFFERENT COVER CROPS AND DESICCATION TIMES ${ }^{1}$
}

\author{
ANA PAULA SANTOS OLIVEIRA ${ }^{2}$, CEITON MATEUS SOUSA ${ }^{2}$, ENDERSON PETRÔNIO DE BRITO FERREIRA ${ }^{3 *}$
}

\begin{abstract}
The common bean requires high levels of nitrogen (N) to achieve high productivity, which can be supplied, at least partially, by the biological nitrogen fixation (BFN). Two field experiments were carried out in the winter season of 2015 aiming to evaluate the effects of different cover crops, desiccation times and the agronomic performance of the common bean inoculated with rhizobia. The experiments were assembled in a randomized block design with four replications, in a factorial split-plot arrangement with two additional treatments $(5 \times 4 \times 2+2)$. The factors were composed of five cover crops, four desiccation times, two seed inoculation treatments and two additional controls $\left(\mathrm{TN}=90 \mathrm{Kg} \mathrm{N} \mathrm{ha}^{-1}\right.$ and $\mathrm{T} 0=$ without $\mathrm{N}$ and without inoculation). The variables analyzed in the cover crops were dry mass (DM) and total nitrogen (Total-N). With the common bean, the chlorophyll content (CC), the number of nodules (NN), the nodule dry weight (NDW), the shoot dry weight (SDW), the root dry weight (RDW) and the grain yield (GY) were evaluated. The results showed that the agronomic performance of the common bean was not affected by the desiccation times of the cover crops, although the amount of Total-N accumulated by cover crops was influenced by sowing times. Inoculation of the common bean promoted an increase in the NN, NDW, CC and SDW. Higher GY of the common bean was achieved with its cropping after Brachiaria brizantha, Brachiaria ruziziensis, millet and fallow.
\end{abstract}

Keywords: Phaseolus vulgaris. No tillage system. Biological nitrogen fixation.

\section{DESEMPENHO DO FEIJOEIRO-COMUM INOCULADO EM RESPOSTA A DIFERENTES PLANTAS DE COBERTURA E ÉPOCAS DE DESSECAÇÃO}

\begin{abstract}
RESUMO - O feijoeiro-comum requer altos níveis de nitrogênio $(\mathrm{N})$ para alcançar elevadas produtividades, os quais podem ser supridos, ao menos parcialmente, pela fixação biológica de N (FBN). Com o objetivo de avaliar os efeitos de diferentes plantas de cobertura e épocas de dessecação no desempenho agronômico do feijoeiro-comum inoculado com rizóbio, foram conduzidos dois experimentos em campo, na safra de inverno 2015. Os experimentos foram implantados em delineamento de blocos ao acaso com quatro repetições, em esquema fatorial de parcelas sub subdivididas com tratamentos adicionais $(5 \times 4 \times 2+2)$. Os fatores foram: cinco plantas de cobertura, quatro épocas de dessecação, dois tratamentos de inoculação das sementes e duas testemunhas $\left(\mathrm{TN}=90 \mathrm{Kg} \mathrm{N}^{-1}\right.$ e $\mathrm{T} 0=$ sem N e sem inoculação). As variáveis analisadas nas plantas de cobertura foram massa seca (MS) e nitrogênio total (N-Total). No feijoeiro-comum avaliou-se teor de clorofila (TC), número de nódulos (NN), massa seca de nódulos (MSN), massa seca da parte aérea (MSPA), massa seca de raiz (MSR) e a produção de grãos (PG). Os resultados mostraram que o desempenho agronômico do feijoeiro-comum não foi afetado pelas épocas de dessecação das plantas de cobertura, embora a quantidade de N-Total acumulada pelas plantas de cobertura tenha sido influenciada pela época de semeadura. A inoculação do feijoeiro-comum promoveu aumento do NN e MSN, do TC e da MSPA do feijoeiro-comum. Em Santo Antônio de Goiás obteve-se maior PG do feijoeiro-comum em cultivo após braquiária brizanta, braquiária ruziziensis, milheto e pousio.
\end{abstract}

Palavras-chave: Phaseolus vulgaris. Semeadura direta. Fixação biológica de nitrogênio.

\footnotetext{
*Corresponding author

${ }^{1}$ Received for publication in $04 / 28 / 2016$; accepted in $11 / 11 / 2016$.

Paper extracted from the Master's degree dissertation of the first author.

${ }^{2}$ Laboratory of Soil, Instituto Federal Goiano, Ceres, GO, Brazil; anapaula.oliveira@ifgoiano.edu.br, cleiton.sousa@ifgoiano.edu.br.

${ }^{3}$ Laboratory of Soil Microbiology, Embrapa Arroz e Feijão, Santo Antônio de Goiás, GO, Brazil; enderson.ferreira@embrapa.br.
} 


\section{INTRODUCTION}

The common bean (Phaseolus vulgaris L.) is a species of great importance in the Brazilian economy. The grain of this crop plays an important role in the diet of the general population. Due to its high nutritional value it is recognized as an excellent source of protein besides containing carbohydrates and minerals (BINOTTI et al., 2009). Brazil is among the greatest producers and consumers of the common bean in the world. In the 2014/15 season, 3.2 million tons were produced in an area of 3.0 million hectares, with an average productivity of $1050 \mathrm{~kg} \mathrm{ha}^{-1}$ (CONAB, 2015).

Currently, this production comes from small and large farms from all Brazilian regions with diversified farming systems. However, only $20 \%$ of the grain production comes from systems using high input, which can reach productivities up to 3,500 $\mathrm{kg} \mathrm{ha}^{-1}$ (EMBRAPA, 2015). The development and availability of new technologies to farmers can reduce the agronomic fragility of most crops, such as the use of biological nitrogen fixation (BNF), a biotechnology that ensures high levels of productivity at low costs.

One of the main weaknesses related to the common bean productivity, is associated with nitrogen $(\mathrm{N})$, which is the most absorbed nutrient and exported by the crop. In this way, the use of nitrogen fertilizers has a significant influence, being able to be limit the production if it is supplied in low quantities or misapplied. Thus, the high costs for the acquisition of $\mathrm{N}$-fertilizers and the environmental impact they cause on the production process and the soil losses, points out the necessity to develop economically and environmentally viable alternatives to N-fertilizers (SILVA; LEMOS; TAVARES, 2006; TOZLU et al., 2012).

The BNF, performed by nitrogen-fixing bacteria inoculated to the seeds of the common bean is an alternative that can supply the crops demand for $\mathrm{N}$ and benefit its production in an efficient and inexpensive way (STRALIOTTO; TEIXEIRA; MERCANTE, 2002).

Associated with this alternative, the use of cover crops also has many benefits to the agricultural environment. The nutrient cycling, the accumulation of organic matter in the soil surface and the $\mathrm{N}$ supply through BNF or absorption and immobilization of the nutrient in its biomass are some of these benefits (SILVA et al., 2008; WUTKE et al., 2009). Thus, the association of the use of cover crops with the use of $\mathrm{BNF}$ in the common bean production becomes an efficient way of achieving high productivity, replacing the use of $\mathrm{N}$-fertilizers. However, according to edaphoclimatic conditions, the definition of straw-forming plants, as well as their management, has been the great barrier to success in different regions of Brazil (KLUTHCOUSKI et al., 2000).

In order to guarantee the beneficial effect of the common bean cultivation inoculated in no-tillage, it is important to know the proper management of cover crops. According to Ferreira et al. (2011), the choice of adequate soil management is an essential factor for the success of using these plants as suppliers of nutrients for the crop.

The objective of this work was to evaluate the effects of cover crops, times of desiccation and inoculation with rhizobia on the agronomic performance of the common bean, as a way of increasing productivity and reducing costs and environmental impacts caused by the use of $\mathrm{N}$-fertilizers.

\section{MATERIAL AND METHODS}

The experiments were conducted during the winter crop season of 2015 in two different areas. One was at Embrapa Arroz e Feijão in the municipality of Santo Antônio de Goiás - GO with a latitude of $16^{\circ} 30^{\prime} 17.32^{\prime \prime} \mathrm{S}$ and a longitude of $49^{\circ} 17^{\prime} 16.52^{\prime \prime} \mathrm{W}$, and with an altitude of $823 \mathrm{~m}$, from April to September. The other one was at the Instituto Federal Goiano - Campus Ceres, Ceres - GO with a latitude of $15^{\circ} 21^{\prime} 18.65$ "S and a longitude of $49^{\circ} 36^{\prime} 26.26^{\prime \prime} \mathrm{W}$, and with an altitude of $600 \mathrm{~m}$, from May to October.

According to the Köppen classification, the climate of the both localities is Aw, a tropical savanna, megathermal. The pluvial regime is well defined, with a rainy season from October to March, with an average annual rainfall of $1,460 \mathrm{~mm}$ in the Santo Antônio de Goiás area and 1,700 mm in Ceres. Rainfall data and the maximum and minimum temperatures observed during the conduction of the experiments are shown in Figure 1.

The variations of the photoperiod as a function of the latitude of the sites and during the period of conduction of the experiments are shown in Figure 2.

The soil in Santo Antônio de Goiás is a Dark Red Latosol, with clay $=349 \mathrm{~g} \mathrm{~kg}^{-1}$; sand $=440 \mathrm{~g} \mathrm{~kg}^{-1}$, and silt $=211 \mathrm{~g} \mathrm{~kg}^{-1}$, while in Ceres it is a Red Latosol, with clay $=267 \mathrm{~g} \mathrm{~kg}^{-1}$; sand $=487 \mathrm{~g} \mathrm{~kg}^{-1}$, and silt $=246 \mathrm{~g} \mathrm{~kg}^{-1}$ (EMBRAPA, 2013). Before the installation of the experiments, chemical analysis of the soil was conducted in accordance with the methodology proposed by EMBRAPA (1997) and the results are shown in Table 1. 

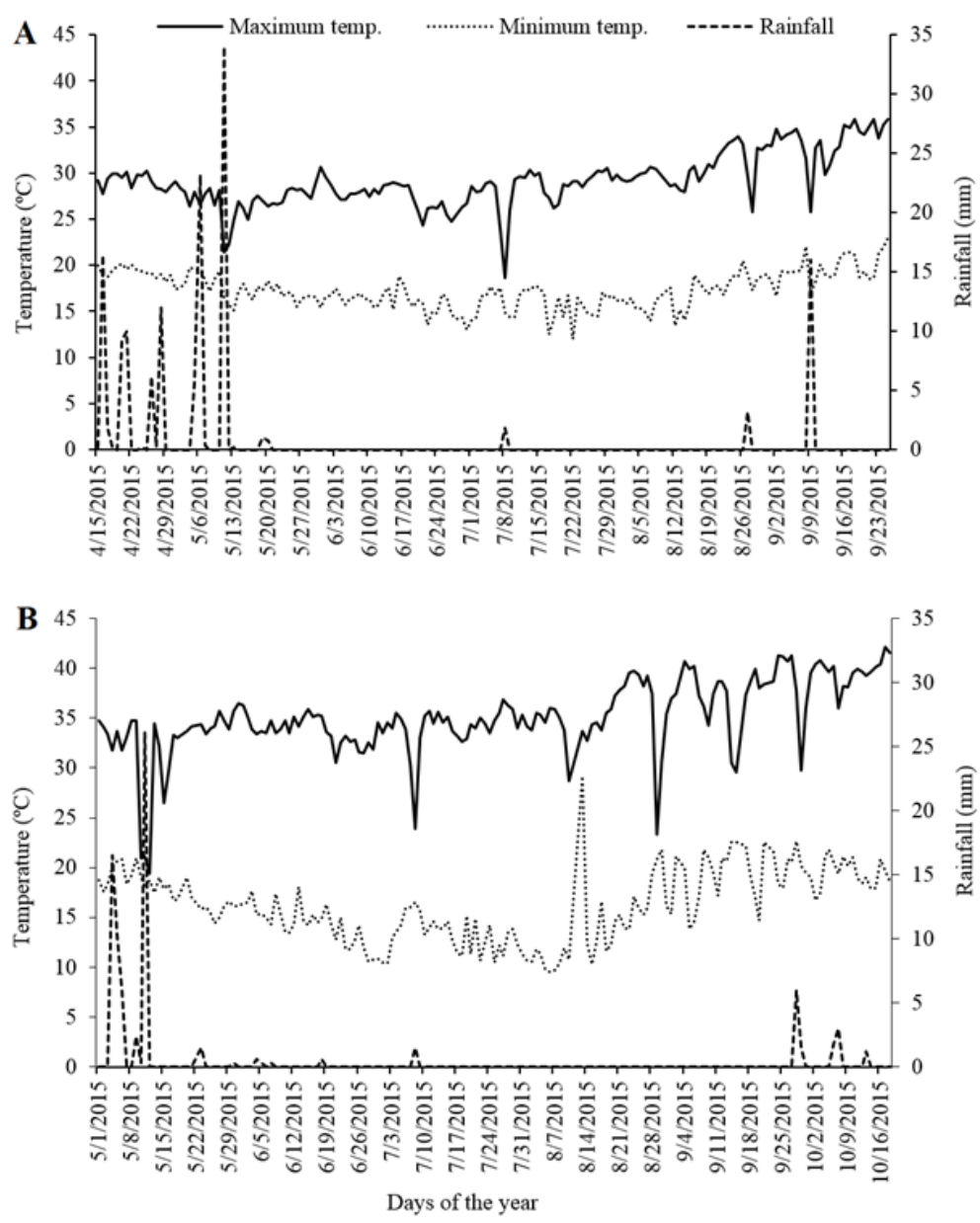

Figure 1. Rainfall, maximum and minimum temperatures during the conduction of the field experiments in Santo Antônio de Goiás (A) and Ceres (B). Data obtained from the meteorological stations of the Embrapa Arroz e Feijão and of the Instituto Federal Goiano - Campus Ceres.

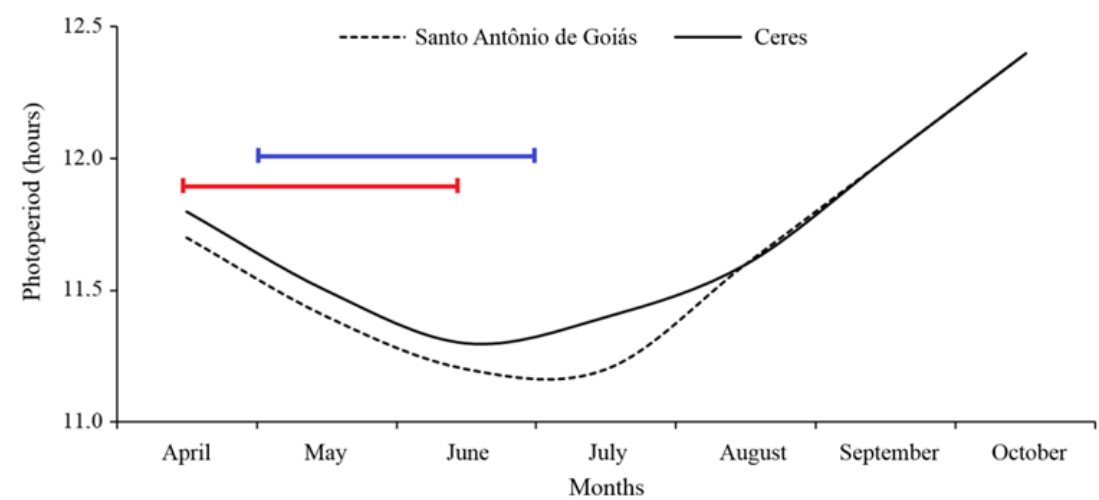

Figure 2. Photoperiod during the conduction of the field experiments in 2015. Red bar corresponds to the period of cultivation of the cover crops in Santo Antônio de Goiás and, blue bar corresponds to the period of cultivation of the cover crops in Ceres. Data obtained from the meteorological stations of the Embrapa Arroz e Feijão and of the Instituto Federal Goiano - Campus Ceres.

Table 1. Chemical characteristics of the soils of the experimental areas before experiments installation in Santo Antônio de Goiás (A) and Ceres (B).

\begin{tabular}{|c|c|c|c|c|c|c|c|c|}
\hline \multirow[b]{2}{*}{ Site } & $\mathrm{pH}$ & $\mathrm{Ca}$ & $\mathrm{Mg}$ & $\mathrm{Al}$ & $\mathrm{H}+\mathrm{Al}$ & $\mathrm{P}$ & $\mathrm{K}$ & M.O \\
\hline & $\mathrm{H}_{2} \mathrm{O}$ & \multicolumn{4}{|c|}{$\mathrm{cmol}_{\mathrm{c}} \mathrm{dm}^{-3}$} & \multicolumn{2}{|c|}{$\mathrm{mg} \mathrm{dm}^{-3}$} & $\mathrm{~g} \mathrm{~kg}^{-1}$ \\
\hline A & 4.9 & 1.4 & 0.5 & 0.1 & 2.3 & 6.4 & 76.0 & 17.0 \\
\hline B & 5.6 & 3.9 & 1.9 & 0.0 & 1.8 & 50.0 & 220.0 & 22.0 \\
\hline
\end{tabular}

Rev. Caatinga, Mossoró, v. 30, n. 3, p. 642 - 652, jul. - set., 2017 
The experimental design used was random blocks with four repetitions with the treatments disposed in a factorial split-plot arrangement with two additional treatments $(5 \times 4 \times 2+2)$, as follows. Five cover crops: millet (Pennisetum americanum), crotalaria (Crotalaria juncea), Brachiaria brizanta (Urochloa brizanta), Brachiaria ruziziensis (Urochloa ruziziensis) and fallow (spontaneous vegetation), with four desiccation periods (18, 11, 4 and 1 day before the common bean sowing in Santo Antônio de Goiás and 22, 15, 8 and 1 day before the common bean sowing in Ceres); two seed inoculation treatments (inoculated and non-inoculated) and two additional control treatments (TN: $90 \mathrm{Kg} \mathrm{N} \mathrm{ha}{ }^{-1} /$ without inoculation and T0: without N/without inoculation). The soil was conventionally prepared by plowing and double harrowing.

The experiments were carried out in two stages. The first one corresponded to the implantation and management of the cover crops and the second one regarding the sowing, management and harvest of the common bean. The common bean was cultivated under no-tillage system on the straw of the cover crops.

The sowing of the cover crops was carried out weekly, in four times. In the area of Santo Antônio de Goiás on 15/04/2015 (time I), on $04 / 22 / 2015$ (time II), on 04/29/2015 (time III) and on 05/06/2015 (time IV) and in Ceres on 05/01/2015 (time I), on 05/07/2015 (time II), on 05/14/2015 (time III) and on $05 / 21 / 2015$ (time IV). The scheduling of the implantation of the cover plants was done to guarantee that in the desiccation time the plants were in the same stage of development.

At 45 days after emergence (AED), random sampling was performed in each plot to evaluate dry matter (DM) and total nitrogen (Total-N) accumulated in the shoots of the cover crops. On the same day, a survey of the spontaneous vegetation that had developed in the plots was also carried out. After sampling for the determination of the biomass, performed on 06/01/2015, 06/08/2015, 06/15/2015 and $06 / 18 / 2015$ in Santo Antônio de Goiás and on $06 / 11 / 2015,06 / 18 / 2015,06 / 25 / 2015$ and $07 / 02 / 2015$ in Ceres, the desiccation of the cover crops was done using glyphosate.

The sowing of the common bean was done on 19/06/2015 in Santo Antônio de Goiás and on 07/07/2015 in Ceres. The seeds of the cultivar Pérola were treated with peat inoculant, in a proportion of $10 \mathrm{~g}$ of inoculant per $\mathrm{kg}$ of seed. The inoculant was composed of the recommended Rhizobium strains for the common bean (SEMIA 4077 and SEMIA 4088 of Rhizobium tropici and SEMIA 4080 of Rhizobium freirei), in a 1:1:1 ratio of each strain, with a final concentration of $10^{9}$ cells per gram of inoculant.

At the R5 phenological stage of the common bean, corresponding to the beginning of flowering, the indirect chlorophyll reading was performed with the Minolta SPAD-502 in the first fully developed leaf, averaging two readings per leaflet, of three plants per plot.

Still at the R5 development stage, the plants were collected. The roots were washed in running water over a 270-mesh sieve to remove excess soil and retain nodules. The nodules were detached from the roots to obtain the number of nodules $(\mathrm{NN})$ and stored in paper bags separately. The nodules, roots and shoots, were dried $\left(65^{\circ} \mathrm{C} ; 72 \mathrm{~h}\right)$ to determine nodule dry weight (NDW), root dry weight (RDW) and shoot dry weight (SDW). The shoots were milled to determine the total nitrogen (Total-N) accumulated in the shoots of the common bean, according to the methodology proposed by Malavolta, Vitti and Oliveira (1997).

At the harvest stage, grain yield (GY) was determined by removing the plants from the central area of the plot $(2 \times 2 \mathrm{~m})$, treading the grains to obtain the weight and converting to $\mathrm{kg} \mathrm{ha}^{-1}$ with the data corrected to $13 \%$ moisture. The determination of grain yield was performed only in the trial conducted in Santo Antônio de Goiás, because a high rate of flower and pod abortion and fungal disease occurred in the experiment conducted in Ceres.

The data obtained in the two stages of the experiment (cover crops and common bean) were submitted to analysis of variance (F test) and when significant differences among treatments were observed, the means were compared by the Scott-Knott test at $5 \%$ of probability. In the second step, orthogonal contrasts test was performed separately between the best treatment and the controls (TN and T0).

\section{RESULTS AND DISCUSSION}

\section{Performance of cover crops according to sowing time}

In Santo Antônio de Goiás the greatest accumulation of dry mass (DM) for crotalaria and millet were obtained in the times I and II. For Brachiaria brizanta and fallow, the highest production of DM was in time II. The studied plants suffered a reduction of the DM in the sowing times III and IV, except for the Brachiaria ruziziensis, which did not change during sowing times (Table 2). 
A. P. S. OLIVEIRA et al.

Table 2. Dry mass of the cover crops $\left(\mathrm{kg} \mathrm{ha}^{-1}\right)$ according to the different sowing times in the municipalities of Santo Antônio de Goiás and Ceres in 2015.

\begin{tabular}{|c|c|c|c|c|}
\hline \multirow{3}{*}{ Cover crops } & \multicolumn{4}{|c|}{ Santo Antônio de Goiás } \\
\hline & \multicolumn{4}{|c|}{ Sowing time } \\
\hline & 15/April (I) & 22/April (II) & 29/April (III) & 06/May (IV) \\
\hline B. brizanta & $500 \mathrm{Cb}$ & $900 \mathrm{Ba}$ & $300 \mathrm{Bb}$ & $200 \mathrm{Bb}$ \\
\hline B. ruziziensis & $300 \mathrm{Ca}$ & $600 \mathrm{Ba}$ & $100 \mathrm{Ba}$ & $100 \mathrm{Ba}$ \\
\hline Crotalaria juncea & $1400 \mathrm{Aa}$ & $1100 \mathrm{Aa}$ & $700 \mathrm{Ab}$ & $300 \mathrm{Bb}$ \\
\hline Millet & $1600 \mathrm{Aa}$ & $1400 \mathrm{Aa}$ & $1000 \mathrm{Ab}$ & $300 \mathrm{Bc}$ \\
\hline \multirow[t]{2}{*}{ Fallow } & $1000 \mathrm{Bb}$ & $1500 \mathrm{Aa}$ & $1000 \mathrm{Ab}$ & $700 \mathrm{Ab}$ \\
\hline & \multicolumn{4}{|c|}{ Ceres } \\
\hline \multirow[t]{2}{*}{ Cover crops } & \multicolumn{4}{|c|}{ Sowing time } \\
\hline & 01/May (I) & 07/May (II) & 14/May (III) & 21/May (IV) \\
\hline B. brizanta & $400 \mathrm{Ba}$ & $400 \mathrm{Ca}$ & $400 \mathrm{Ba}$ & $300 \mathrm{Ba}$ \\
\hline B. ruziziensis & $300 \mathrm{Ba}$ & $300 \mathrm{Ca}$ & $300 \mathrm{Ba}$ & $300 \mathrm{Ba}$ \\
\hline Crotalaria juncea & $1.100 \mathrm{Aa}$ & $1.000 \mathrm{Ba}$ & $1.100 \mathrm{Aa}$ & $800 \mathrm{Aa}$ \\
\hline Millet & $1.100 \mathrm{Ab}$ & $1.400 \mathrm{Aa}$ & $1.200 \mathrm{Ab}$ & $1.000 \mathrm{Ab}$ \\
\hline Fallow & $500 \mathrm{Ba}$ & $600 \mathrm{Ca}$ & $300 \mathrm{Ba}$ & $400 \mathrm{Ba}$ \\
\hline
\end{tabular}

Mean followed by the same capital letter in the column and by the same lowercase letter are not significantly different by the Skott-Knott's test $(\mathrm{p}<0.05)$.

The sowing times influenced the soil covering by brachiaria brizanta, crotalaria, millet and fallow in Santo Antônio de Goiás. For the Brachiaria ruziziensis, sowing times did not influence the amount of DM produced. Barbosa et al. (2013) evaluated two sowing times of cover crops in the off time, and also verified the reduction of dry mass in the last sowing time of the Brachiaria brizanta, crotalaria and fallow.

At time I, in Santo Antônio de Goiás, the plants with the greatest accumulation of DM, were crotalaria and millet, and in time II and III, crotalaria, millet and fallow. In time IV, the fallow was superior to the other cover crops, obtaining greater DM. At the times I, II and III, the brachiaria had the lowest accumulation of DM (Table 2).

Considering the DM production, in Santo Antônio de Goiás (April), millet, crotalaria and spontaneous vegetation (fallow) had better yields and the brachiaria showed lower production. Torres, Pereira and Fabian (2008) obtained similar results in a Cerrado soil, with higher DM yields for millet, crotalaria and fallow, with the plants sown in April.

Pacheco et al. (2011), in an area of Santo Antônio de Goiás - GO and the same time of cultivation of the cover crops, presented results compatible with those of this study. The millet obtained higher yields of DM, whereas the Brachiaria brizanta and Brachiaria ruziziensis were inferior. In an area of Rio Verde - GO, with the plants sown on $04 / 10 / 2008$, they obtained DM production for millet, Brachiaria ruziziensis and fallow of 3600,1000 and $900 \mathrm{~kg} \mathrm{ha}^{-1}$, respectively.

Although millet, crotalaria and fallow have obtained better yields of DM in relation to both brachiarias, the net production is still considered low for adequate soil covering (ALVARENGA et al., 2001). Carvalho et al. (2013) also found low accumulation of DM in the winter season, where cultivation in Cerrado soil during this period is not favorable for the growth and development of the plants.

In the Cerrado region, the dry climate in the winter and short photoperiod does not favor the establishment of a soil covering with sufficient quantity and rusticity to supply material to the soil until sowing of the subsequent crop (ALVARENGA et al., 2001). This fact represents a big challenge for the establishment of the no-tillage system in this region.

In Ceres the greatest accumulation of DM for millet was obtained in time II. The other plants did not change during sowing times. Among the cover crops, crotalaria and millet had higher DM production in times I, III and IV. The millet was higher than the other plants in time II, while the both brachiarias and fallow showed the lowest yields of DM at all sowing times (Table 2).

Under the conditions of the study in the Ceres area, both brachiarias and fallow showed the lowest yields of DM. In this case, crotalaria and millet obtained the greatest accumulation. Torres et al. 
A. P. S. OLIVEIRA et al.

(2014) found similar results using millet, crotalaria and brachiaria in the dry period, in which millet showed higher production of DM, which shows the good adaptation of this plant to the climate and soil of the Cerrado. Brachiaria presented the lowest yields, with a DM production of less than $4000 \mathrm{~kg} \mathrm{ha}^{-1}$. According to Alvarenga et al. (2001), the amount of DM considered ideal for a good soil covering is $6000 \mathrm{~kg} \mathrm{ha}^{-1}$. This production is also sufficient to compensate for the decomposition rates of the straw.

These results show that in the two study sites the late planting compromised the growth of the cover crops. This fact may be associated with alteration in photoperiod, water availability and temperature between sowing times, considering that the plants have photoperiodic responses.

In Santo Antônio de Goiás the highest accumulation of Total-N for millet was observed in time I. For the fallow, the greatest accumulation of Total-N was in time II and, for Brachiaria brizanta and crotalaria, it was at the times I and II. The Brachiaria brizanta, crotalaria and fallow species suffered a reduction of Total-N in sowing times III and IV. Millet showed a reduction in Total-N content in times II, III and IV. The Brachiaria ruziziensis did not vary between sowing times (Table 3 ).

Table 3. Total nitrogen $\left(\mathrm{kg} \mathrm{ha}^{-1}\right)$ accumulated by the cover crops according to the different sowing times in the municipalities of Santo Antônio de Goiás and Ceres in 2015.

\begin{tabular}{|c|c|c|c|c|}
\hline \multirow{3}{*}{ Cover crops } & \multicolumn{4}{|c|}{ Santo Antônio de Goiás } \\
\hline & \multicolumn{4}{|c|}{ Sowing time } \\
\hline & 15/April (I) & 22/abril (II) & 15/April (I) & 06/maio (IV) \\
\hline B. brizanta & $25.8 \mathrm{Ca}$ & $34.4 \mathrm{Ba}$ & $12.8 \mathrm{Bb}$ & $12.3 \mathrm{Ab}$ \\
\hline B. ruziziensis & $13.1 \mathrm{Ca}$ & $21.0 \mathrm{Ba}$ & $5.6 \mathrm{Ba}$ & 4.9 Aa \\
\hline Crotalaria juncea & $47.6 \mathrm{Ba}$ & $39.4 \mathrm{Ba}$ & $27.5 \mathrm{Ab}$ & $12.2 \mathrm{Ab}$ \\
\hline Millet & $75.3 \mathrm{Aa}$ & $52.0 \mathrm{Ab}$ & $44.2 \mathrm{Ab}$ & $12.5 \mathrm{Ac}$ \\
\hline \multirow[t]{2}{*}{ Fallow } & $34.9 \mathrm{Cb}$ & $57.6 \mathrm{Aa}$ & $40.7 \mathrm{Ab}$ & $24.2 \mathrm{Ab}$ \\
\hline & \multicolumn{4}{|c|}{ Ceres } \\
\hline \multirow[t]{2}{*}{ Cover crops } & \multicolumn{4}{|c|}{ Sowing time } \\
\hline & 01/May (I) & 07/maio (II) & 01/May (I) & 21/maio (IV) \\
\hline B. brizanta & $12.7 \mathrm{Ba}$ & $13.8 \mathrm{Ba}$ & $12.8 \mathrm{Ba}$ & $9.0 \mathrm{Ba}$ \\
\hline B. ruziziensis & $8.8 \mathrm{Ba}$ & $11.3 \mathrm{Ba}$ & $10.3 \mathrm{Ba}$ & $9.0 \mathrm{Ba}$ \\
\hline Crotalaria juncea & $33.9 \mathrm{Aa}$ & $27.1 \mathrm{Aa}$ & $31.7 \mathrm{Aa}$ & $28.8 \mathrm{Aa}$ \\
\hline Millet & $33.2 \mathrm{Aa}$ & $35.2 \mathrm{Aa}$ & $32.6 \mathrm{Aa}$ & $25.3 \mathrm{Aa}$ \\
\hline Fallow & $14.7 \mathrm{Ba}$ & $15.7 \mathrm{Ba}$ & $9.8 \mathrm{Ba}$ & $14.7 \mathrm{Ba}$ \\
\hline
\end{tabular}

Mean followed by the same capital letter in the column and by the same lowercase letter are not significantly different by the Skott-Knott's test $(\mathrm{p}<0.05)$.

In this case, in Santo Antônio de Goiás, sowing of millet up to time I obtained greater accumulation of Total-N in the straw, whereas for Brachiaria brizanta and crotalaria, a greater accumulation was obtained until time II. At sowing time I, millet presented higher accumulation of Total-N in relation to crotalaria, whereas the both brachiarias and fallow were inferior to this. The plants that had the greatest accumulation of Total-N in time II were millet and fallow, and in time III, millet, crotalaria and fallow. In time IV, the plants did not differ among themselves (Table 3 ).

On the choosing of the cover crops it is important to consider, in addition to the potential of dry mass production, its nitrogen accumulation and nutrient release dynamics, especially in regions where climatic conditions favor straw decomposition
(DONEDA et al., 2012). In the conditions of the study in Santo Antônio de Goiás, the brachiaria in the month of April presented the lowest dry mass production and the lowest accumulation of Total-N in the straw. However, it is important to emphasize that cover crops have other benefits, besides the production of straw and $\mathrm{N}$ accumulation. They can improve soil structure, interaction with other organisms, nutrient cycling, a decrease of the soil temperature, a reduction of erosion (WUTKE et al., 2009), among other factors that should be considered for choosing the cover crop to be used.

Millet, crotalaria and fallow, cropped up to April, obtained levels of Total-N above $30 \mathrm{~kg} \mathrm{ha}^{-1}$ (Table 3). The values found in this study for these crops, in the area of Santo Antônio de Goiás, at all sowing times, were higher than the values found by 
Torres, Pereira and Fabian (2008). For the millet grown at time I, an Total-N value equal to $75.3 \mathrm{~kg} \mathrm{ha}^{-1}$ was observed, which is twice as high as the values found by Pacheco et al. (2011). If all $\mathrm{N}$ were converted to the subsequent crop, the amount found in this study corresponds to $70 \%$ of the amount of $\mathrm{N}$ necessary for the cultivar Pérola to reach $90 \%$ of maximum productivity (SANTOS et al., 2003)

In Ceres the sowing time did not affect the Total-N contents. Also, no significant difference was observed between millet and crotalaria, whereas both brachiarias and fallow were lower than millet and crotalaria at all sowing times (Table 3).

According to Primavesi, Primavesi and Armelin (2002), the amount of nutrient accumulated depends on the species, soil fertility, management, $\mathrm{C} / \mathrm{N}$ ratio, sowing time and climatic conditions. However, under the conditions of this study, the Total-N amounts accumulated by the cover crops, regardless of species, site or sowing time, are not enough to supply the demand of $\mathrm{N}$ for the common bean, since this crop needs around $100 \mathrm{~kg} \mathrm{~N} \mathrm{ha}^{-1}$ to reach high yields (BORDIN et al., 2003; SANTOS et al., 2003; SILVEIRA; BRAZ; DIDONET, 2003).

\section{Response of common bean to different cover}

\section{crops and times of desiccation}

The different times of desiccation of the cover crops, using the herbicide glyphosate, as well as the interaction between application times and cover crops in the two sites, did not show significant effects on nodulation, growth and productivity of common bean. According to Prata et al. (2005), the herbicide glyphosate, when applied in an Oxisol, is rapidly adsorbed by the soil particles, which prevents its desorption to the soil solution. Thus, it is possible that the absence of the residual effect of glyphosate on the common bean nodulation, observed in this work, is associated to the absence of residue in the soil solution. The effects of inoculation in Santo Antônio de Goiás were significant for the number of nodules, chlorophyll content and dry mass of the shoots, and in Ceres, for the number of nodules, dry mass of nodules and root dry mass. The effects of the cover crops in Santo Antônio de Goiás were significant for productivity. In Santo Antônio de Goiás, the inoculated plants presented a higher number of nodules, chlorophyll content and shoot dry weight in relation to the treatment without inoculation. The other parameters evaluated did not differ among treatments (Table 4).

Table 4. Number of nodules (NN- units plant ${ }^{-1}$ ), nodule dry weight (NDW- mg plant ${ }^{-1}$ ), chlorophyll content (CC- SPAD), shoot dry weight (SDW- g plant ${ }^{-1}$ ), root dry weight (RDW- g plant ${ }^{-1}$ ) and total nitrogen (Total-N- g kg $^{-1}$ ) of the common bean with and without inoculation in Santo Antônio de Goiás and Ceres in 2015.

\begin{tabular}{lcccccc}
\hline \multirow{2}{*}{ Treatment } & \multicolumn{5}{c}{ Santo Antônio de Goiás } \\
\cline { 2 - 7 } & $\mathrm{NN}$ & NDW & CC & SDW & RDW & Total-N \\
\hline With inoculation & $28.8 \mathrm{a}$ & $56.2 \mathrm{a}$ & $39.8 \mathrm{a}$ & $5.2 \mathrm{a}$ & $0.4 \mathrm{a}$ & $29.1 \mathrm{a}$ \\
Without inoculation & $22.4 \mathrm{~b}$ & $46.7 \mathrm{a}$ & $39.2 \mathrm{~b}$ & $4.5 \mathrm{~b}$ & $0.4 \mathrm{a}$ & $29.9 \mathrm{a}$
\end{tabular}

\begin{tabular}{lcccccc} 
Treatment & \multicolumn{1}{c}{ NN } & NDW & CC & SDW & RDW & Total-N \\
\cline { 2 - 7 } & $30.5 \mathrm{a}$ & $84.7 \mathrm{a}$ & $45.4 \mathrm{a}$ & $6.1 \mathrm{a}$ & $0.4 \mathrm{~b}$ & $24.8 \mathrm{a}$ \\
With inoculation & $21.0 \mathrm{~b}$ & $58.7 \mathrm{~b}$ & $45.0 \mathrm{a}$ & $5.8 \mathrm{a}$ & $0.5 \mathrm{a}$ & $24.5 \mathrm{a}$ \\
\hline
\end{tabular}

Mean followed by the same letter in the column are not significantly different by the Skott-Knott's test $(\mathrm{p}<0.05)$.

The NN of the inoculated plants in Santo Antônio de Goiás and Ceres were about 29 and 31 nodules plant ${ }^{-1}$, respectively, being superior to the $\mathrm{NN}$ of the plants without inoculation in about $28 \%$ and $45 \%$ in Santo Antônio de Goiás and Ceres, respectively. The NN above 15 units plant ${ }^{-1}$ is already indicative of good symbiotic efficiency, but the formation of small-sized nodules that compromise the efficiency of BNF may occur (CARDOSO et al., 2009; FONSECA et al., 2013). Pelegrin et al. (2009) worked with the Pérola cultivar of the common bean inoculated and cultivated in a conventional system. These authors reported values lower than those observed in this study, with NN of

\section{6 plant $^{-1}$ and NDW of 3.8 g plant $^{-1}$.}

It was verified in Santo Antônio de Goiás that the treatment without inoculation also presented a NN above 15 plant $^{-1}$. This result is associated with the presence of native rhizobia strains capable of nodulating the common bean. Brito et al. (2015) also found expressive nodulation in common bean plants without inoculation. According to these authors, two areas of Santo Antônio de Goiás showed high native Rhizobium population, about $10^{5}$ cells $\mathrm{g}^{-1}$ soil.

The importance of nodulation can be verified in the gain of chlorophyll content (CC) and shoot dry weight (SDW) of the treatment with inoculation (Table 4). The values found for the $\mathrm{CC}$ can be 
indicative of the availability of $\mathrm{N}$ for the plants, since $\mathrm{N}$ is present in the chlorophyll molecule. However, the presence of a greater amount of SDW can be correlated with the greater development of the shoots of the plants (Table 4).

In Ceres, the plants inoculated with rhizobia had higher values of NN and NDW, whereas the treatment without inoculation showed higher value only for RDW (Table 4). In the two study areas, the inoculation with selected rhizobia does not exclude the possibility of native strains promoting nodulation, but the inoculant strains, besides efficient in the BNF, are competitive to overcome the native ones and guarantee greater nodulation (MATOSO, KUSDRA, 2014).

In this work, in the two study areas, greater NN and NDW were observed in the plants that had been inoculated, with consequent greater growth of the plants represented by the SDW. However, in Santo Antônio de Goiás, the difference among the treatments was lower, which suggests a greater competitiveness of the native strains. It was observed that the common bean cultivated in Santo Antônio de Goiás over brachiaria brizanta straw, independent of the desiccation time, had the highest $\mathrm{NN}$, while on the straw of the other plants there was no significant difference. In Ceres, it was observed that the common bean cultivated over crotalaria straw, regardless of the time of desiccation, had the lowest $\mathrm{NN}$, whereas on the straw of the other plants there was no significant difference (Figure 3). The conditions provided by the no-tillage system with adequate soil covering benefit the development of microorganisms, especially brachiaria brizanta (BARROTI; NAHAS, 2000), favoring the microbial population due to the deposition of organic residues, the amount of roots and the amount of water retained in the soil (BARROTI, NAHAS, 2000; PEREZ, RAMOS; McMANUS, 2004).

- B. brizanta $\square$ B. ruziziensis

\section{Crotalaria $\square$ Millet $\square$ Fallow}

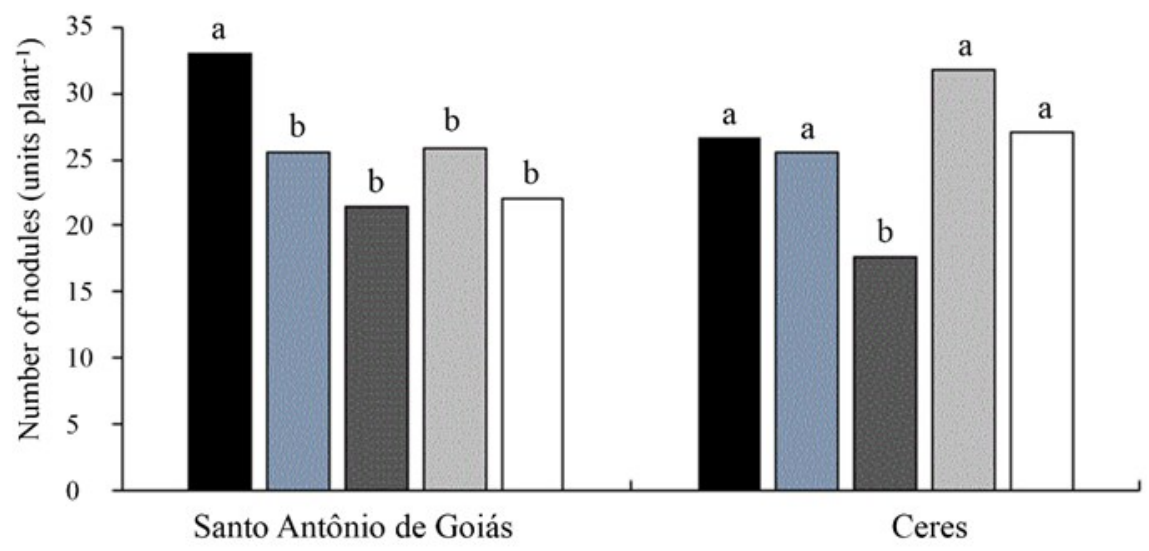

Figure 3. Number of nodules of the common bean cultivated after different cover crops in Santo Antônio de Goiás and Ceres in 2015.

The GY of the common bean obtained in Santo Antônio de Goiás did not show significant differences among the croppings after brachiaria brizanta, brachiaria ruziziensis, millet and fallow. These had a higher GY in relation to the cultivation after crotalaria (Figure 4). Therefore, legume straw did not favor increased productivity, while the use of grasses allowed higher yields for the crop. According to Monegat (1991), the high $\mathrm{C} / \mathrm{N}$ ratio and the high lignin contents of the grass straw results in the slow rate of decomposition making possible the beneficial effects in the long term. Nunes et al. (2006) obtained higher yields of the common bean with the use of grasses as cover crops under no-tillage.

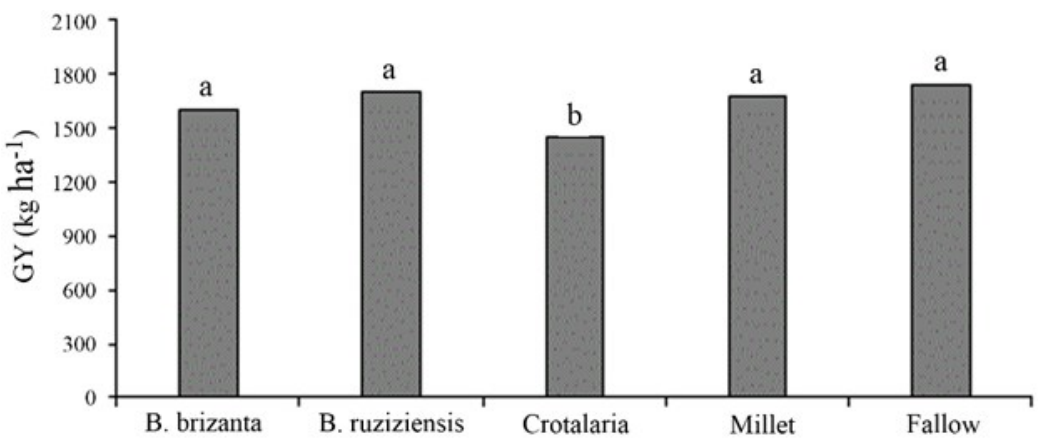

Figure 4. Grain yield (GY) of the common bean cultivated after different cover crops in Santo Antônio de Goiás and Ceres in 2015 . 
In Ceres, it was not possible to obtain productivity data, since the late sowing of the common bean resulted in a high rate of flower drop and pod abortion. These facts were a result of high temperatures (up to $40^{\circ} \mathrm{C}$ ) during the flowering period (Figure 1). According to Massignam et al. (1998), the climatic element that exerts most influence on the percentage of pod growth is the temperature, so that the optimal average temperature for the common bean cultivation varies between $20^{\circ} \mathrm{C}$ to $30^{\circ} \mathrm{C}$ (THUNG; KLUTHCOUSKI; AIDAR, 2004). Therefore, sowing of the common bean should be carried out in the period when the flowering does not coincide with the occurrence of temperatures above $28^{\circ} \mathrm{C}$ (MASSIGNAM et al., 1998).

Table 5. Contrast test of the grain yield $\left(\mathrm{GY}-\mathrm{kg} \mathrm{ha}^{-1}\right)$ of the common bean cultivated after fallow (TP), nitrogen treatment (TN) and the absolute treatment (T0) in Santo Antônio de Goiás in 2015.

\begin{tabular}{|c|c|c|c|}
\hline \multicolumn{2}{|c|}{ Contrast 1} & \multicolumn{2}{|c|}{ Contrast 2} \\
\hline Fallow & Nitrogen treatment & Fallow & absolute treatment \\
\hline $1739.5 \mathrm{a}$ & $1832.1 \mathrm{a}$ & $1739.5 \mathrm{a}$ & $1251.1 \mathrm{~b}$ \\
\hline
\end{tabular}

Mean followed by the same letter within the same contrast are not significantly different by the Skott-Knott's test ( $\mathrm{p}<0.05)$.
Contrast 2 showed a significant difference between the common bean grown on FS-TP and absolute control (T0) (Table 5). In this case, the treatment with fallow increased productivity by $40.5 \%$ over the absolute control. Ferreira et al. (2011) stated that the highest productivity of the common bean occurs under no-tillage system, as compared to a conventional system, and that these yields are highly correlated with the amount of $\mathrm{N}$ accumulated by the cover crops. The performance of the common bean inoculated with bacteria from the rhizobia group and cultivated under no-tillage can overcome production with the use of $\mathrm{N}$-fertilizers, in addition to reducing costs and making the productive system sustainable

\section{CONCLUSIONS}

The different times of desiccation of the cover crops do not influence the nodulation, growth and agronomic performance of the common bean.

The amount of the total nitrogen accumulated by the cover crops is influenced by the sowing time.

The inoculation of the common bean promotes an increase in the number of nodules, nodule dry weight, chlorophyll content and shoot dry weight of the common bean.

In Santo Antônio de Goiás a higher it was cultivated after Brachiaria brizanta, Brachiaria ruziziensis, millet and fallow. productivity of the common bean was obtained when
The common bean cultivation on the fallow straw (FS-TP), in which grass predominated; although it did not present statistical difference with the treatments with the both brachiarias and the millet, obtained the highest GY, reaching a productivity of $1739.5 \mathrm{~kg} \mathrm{ha}^{-1}$ (Figure 4). Contrast 1 between this treatment (FS-TP) and the nitrogen control (TN) showed no significant difference (Table $5)$. This shows the efficiency of the common bean cultivation in no-tillage without the use of N-fertilizer. Souza, Soratto and Pagani (2011) observed that $\mathrm{N}$-fertilization did not influence the GY of the common bean grown on weed straw in no-tillage, which may be related to the $\mathrm{N}$ release from the plant residues.

\section{ACKNOWLEDGMENTS}

The authors thank FAPEG (Fundação de Amparo Á Pesquisa do Estado de Goiàs) for the scholarship granted to Ana Paula Santos Oliveira. Enderson P. de B. Ferreira is research fellow from $\mathrm{CNPq}$, grant number 310059/2013-5. The authors also thanks to Mr. Richard Melton for grammar review of the manuscript.

\section{REFERENCES}

ALVARENGA, R. C. et al. Plantas de cobertura de solo para sistema plantio direto. Informe Agropecuário, Belo Horizonte, v. 22, n. 208, p. 25-36, 2001.

BARBOSA, C. E. M. et al. Análise da matéria seca em culturas de entressafra sob efeito da palha em região de Cerrado e fitossociologia da comunidade infestante. Revista de Ciências Agroveterinárias, Lages, v. 12, n. 1, p. 39-50, 2013.

BARROTI, G.; NAHAS, E. População microbiana total e solubilizadora de fosfato em solo submetido a diferentes sistemas de cultivo. Pesquisa Agropecuária Brasileira, Brasília, v. 35, n. 10, p. 2043-2050, 2000.

BINOTTI, F. F. S. et al. Fontes, doses e modo de aplicação de nitrogênio em feijoeiro no sistema plantio direto. Bragantia, Campinas, v. 68, n. 2, p. 473-481, 2009. 
BORDIN, L. et al. Sucessão de cultivo de feijão-arroz com doses de adubação nitrogenada após adubação verde, em semeadura direta. Bragantia, Campinas, v. 62, n. 2, p. 235-241, 2003.

BRITO, L. F. et al. Resposta do Feijoeiro Comum à Inoculação com Rizóbio e Suplementação com Nitrogênio Mineral em Dois Biomas Brasileiros. Revista Brasileira de Ciência do Solo, Viçosa, v. 39, n. 4, p. 981-992, 2015.

CARDOSO; J. D. et al. Relationship between total nodulation and nodulation at the root crown of peanut, soybean and common bean plants. Soil Biology and Biochemistry, Oxford, v. 41, n. 8, p. 1760-1763, 2009.

CARVALHO, W. P. et al. Desempenho agronômico de plantas de cobertura usadas na proteção do solo no período de pousio. Pesquisa Agropecuária Brasileira, Brasília, v. 48, n. 2, p. 157-166, 2013.

COMPANHIA NACIONAL

DE

ABASTECIMENTO - CONAB. Acompanhamento de safra brasileira: grãos, primeiro levantamento, outubro 2015. Brasília, 2015. Disponível em: $<$ http:// www.conab.gov.br/OlalaCMS/uploads/ arquivos/15_10_28_17_24_01_boletim_graos_outub ro 2015.pdf' $>$. Acesso em: 03 nov. $201 \overline{5}$.

DONEDA, A. et al. Fitomassa e decomposição de resíduos de plantas de cobertura puras e consorciadas. Revista Brasileira de Ciência do Solo, Viçosa, v. 36, n. 6, p. 1714-1723, 2012.

EMPRESA BRASILEIRA DE PESQUISA AGROPECUÁRIA - EMBRAPA. Manual de métodos de análises de solo. 2. ed. Rio de Janeiro, RJ: Embrapa Solos, 1997. 212 p.

EMPRESA BRASILEIRA DE PESQUISA AGROPECUÁRIA - EMBRAPA. Sistema brasileiro de classificação de solos. 3 . ed. Rio de Janeiro, RJ: Embrapa Solos, 2013. 353 p.

EMPRESA BRASILEIRA DE PESQUISA AGROPECUÁRIA - EMBRAPA. Impacto Ambiental. Brasília, 2015. Disponível em: $<$ https:// www.agencia.cnptia.embrapa.br/gestor/feijao/arvore/ CONTAG01_15_20102006143651.html>. Acesso em: 08 jan. 2016.

FERREIRA, E. P. B. et al. Produtividade do feijoeiro comum influenciada por plantas de cobertura e sistemas de manejo do solo. Revista Brasileira de Engenharia Agrícola e Ambiental. Campina Grande, v. 15, n. 7, p. 695-701, 2011.

FONSECA, G. G. et al. Resposta de cultivares de feijoeiro-comum à inoculação das sementes com duas estirpes de rizóbio. Bioscience Journal, Uberlândia, v. 29, n. 6, p. 1778-1787, 2013.

KLUTHCOUSKI, J. et al. Manejo do solo e o rendimento de soja, milho, feijão e arroz em plantio direto. ScientiaAgricola, Piracicaba, v. 57, n. 1, p. 97-104, 2000

MALAVOLTA, E.; VITTI, G. C.; OLIVEIRA, S. A. Avaliação do estado nutricional das plantas: princípios e aplicações. 2. ed. Piracicaba, SP: POTAFOS, 1997. 319 p.

MASSIGNAM, A. M. et al. Ecofisiologiado feijoeiro. II - redução do rendimento pela ocorrência de altas temperaturas no florescimento. Revista Brasileira de Agrometeorologia, Santa Maria, v. 6 , n. 1, p. $41-45,1998$.

MATOSO, S. C. G.; KUSDRA, J. F. Nodulação e crescimento do feijoeiro em resposta à aplicação de molibdênio e inoculante rizobiano. Revista Brasileira de Engenharia Agrícola e Ambiental, Campina Grande, v. 18, n. 6, p. 567-573, 2014.

MONEGAT, C. Plantas de cobertura do solo: características e manejo em pequenas propriedades. 2. ed. Chapecó, SC: Edição do autor, 1991. $336 \mathrm{p}$.

NUNES, U. R. et al. Produção de palhada de plantas de cobertura e rendimento do feijão em plantio direto. Pesquisa Agropecuária Brasileira, Brasília, v. 41, n. 6, p. 943-948, 2006.

PACHECO, L. P. et al. Produção de fitomassa e acúmulo e liberação de nutrientes por plantas de cobertura na safrinha. Pesquisa Agropecuária Brasileira, Brasília, v. 46, n. 1, p. 17-25, 2011.

PELEGRIN, R. et al. Resposta da cultura do feijoeiro à adubação nitrogenada e à inoculação com rizóbio. Revista Brasileira de Ciência do Solo, Viçosa, v. 33, n. 1, p. 219-226, 2009.

PEREZ, K. S.; RAMOS, M. L. G.; McMANUS, C. Carbono da biomassa microbiana em solo cultivado com soja sob diferentes sistemas de manejo nos Cerrados. Pesquisa Agropecuária Brasileira, Brasília, v. 39, n. 6, p. 567-573, 2004.

PRATA, F. et al. Comportamento do glifosato num Latossolo Vermelho sob plantio direto e convencional. Revista Brasileira de Ciência do Solo, Viçosa, v. 29, n. 1, p. 61-69, 2005.

PRIMAVESI, O.; PRIMAVESI, A. C.; ARMELIN, M. J. A. Qualidade mineral e degradabilidade potencial de adubos verdes conduzidos sobre latossolos, na região tropical de São Carlos, SP, 
Brasil. Revista de Agricultura, Piracicaba, v. 77, n. 1, p. 89-103, 2002.

SANTOS, A. B. et al. Resposta do feijoeiro ao manejo de nitrogênio em várzeas tropicais. Pesquisa Agropecuária Brasileira, Brasília, v. 38, n. 11, p. 1265-1271, 2003.

SILVA, E. C. et al. Utilização do nitrogênio da palha de milho e de adubos verdes pela cultura do milho. Revista Brasileira de Ciência do Solo, Viçosa, v. 32, n. especial, p. 2853-2861, 2008.

SILVA, T. R. B.; LEMOS, L. B.; TAVARES, C. A. Produtividade e característica tecnológica de grãos em feijoeiro adubado com nitrogênio e molibdênio. Pesquisa Agropecuária Brasileira, Brasília, v. 41, n. 5 p. $739-745,2006$.

SILVEIRA, P. M.; BRAZ, A. J. B. P.; DIDONET, A. D. Uso do clorofilômetro como indicador da necessidade de adubação nitrogenada em cobertura no feijoeiro. Pesquisa Agropecuária Brasileira, Brasília, v. 38, n. 9, p. 1.083-1.087, 2003.

SOUZA, E. F. C.; SORATTO, R. P.; PAGANI, F. A. Aplicação de nitrogênio e inoculação com rizóbio em feijoeiro cultivado após milho consorciado com braquiária. Pesquisa Agropecuária Brasileira, Brasília, v. 46, n. 4, p. 370-377, 2011.

STRALIOTTO, R.; TEIXEIRA, M. G.; MERCANTE, F. M. Fixação biológica de nitrogênio. In: AIDAR, H.; KLUTHCOUSKI, J.; STONE, L. F. (Eds.). Produção de feijoeiro comum em várzeas tropicais. Santo Antônio de Goiás: Embrapa Arroz e Feijão, 2002. p. 122-153.

THUNG, M.; KLUTHCOUSKI, J.; AIDAR, H. Produção de sementes sadias de feijão comum em várzeas tropicais. Santo Antônio de Goiás: Embrapa Arroz e Feijão, 2004. Disponível em: $<$ https://sistemasdeproducao.cnptia.embrapa.br/ FontesHTML/Feijao/FeijaoVarzeaTropical/ efeitos_temperatura.htm>. Acesso em: 04 jan. 2016.

TORRES, J. L. R.; PEREIRA, M. G.; FABIAN, A. J. Produção de fitomassa por plantas de cobertura e mineralização de seus resíduos em plantio direto. Pesquisa Agropecuária Brasileira, Brasília, v. 43, n. 3, p. 421-428, 2008.

TORRES, J. L. R. et al. Produção de fitomassa e decomposição de resíduos culturais de plantas de coberturas no cultivo da soja em sucessão. Revista Caatinga, Mossoró, v. 27, n. 3, p. 247-253, 2014.

TOZLU, E. et al. Effect of Some Plant Growth Promoting Bacteria on Yield, Yield Components of Dry Bean (Phaseolus vulgaris L. cv. Aras 98).
Journal of the Agricultural Faculty, Erzurum, v. 43 , n. 2, p. 101-106, 2012.

WUTKE, E. B. et al. Adubação verde no Estado de São Paulo. Campinas, SP: CATI, 2009. 89 p. 